Boise State University

ScholarWorks

University Author Recognition Bibliography:

2020

The Albertsons Library

$5-2020$

Inclusive Open Education: Presumptions, Principles, and Practices

Benjamin Croft

Boise State University

Monica Brown

Boise State University

This is an Accepted Manuscript of an article published by Routledge, an imprint of Taylor \& Francis Group, in

Distance Education on May 2020, available online at doi: 10.1080/01587919.2020.1757410 
This is an author-produced, peer-reviewed version of this article. The final, definitive version of this document can be found online at Distance

Education, published by Routledge. Copyright restrictions may apply. doi: 10.1080/01587919.2020.1757410

\title{
Inclusive Open Education: Presumptions, Principles, and Practices
}

\author{
Benjamin Croft \\ Extended Studies \\ Boise State University \\ Boise, ID, US
}

\author{
Monica Brown \\ Extended Studies \\ Boise State University \\ Boise, ID, US
}

\begin{abstract}
Open education has long been forwarded as a producer of equity. However, there currently exists a lack of critical engagement with issues of justice in open educational practices (OEP). While the affordances of open education have potential for increasing equity, creating knowledge alongside learners is inherently rife with complexities for inclusion and diversity. As online faculty build relationships with and between students and engage in unconventional but authentic instruction, they must be cognizant of the ways in which historically underrepresented populations are systematically marginalized and might be excluded from full participation. This paper seeks to investigate tensions at the nexus of OEP and social justice, identify underlying principles of inclusive OEP, and offer initial strategies on using OEP inclusively and in alignment with a social justice framework.
\end{abstract}

Keywords: marginalization; open education; open educational practices; open pedagogy; social identity; social justice

\section{Introduction}

Open education has been widely regarded as progressive, disruptive, and revolutionary in regard to student engagement (Hegarty, 2015) and academic achievement (DeRosa \& Robison, 2017; Winitzky-Stephens \& Pickavance, 2017). The open education movement spans a wide range of perspectives, many of which center the promise of advancing liberal education, broadening access to education (Ehlers, 2011), democratizing knowledge production and consumption (DeRosa \& Jhangiani, 2017), and closing equity gaps among student populations (Colvard, Watson, Park, 2018). While open education has been used in various forms for decades (DeRosa \& Jhangiani, 2017; Cronin, 2017; Rolfe, 2017), contemporary developments have created momentum in the exploration and creation of open education tools.

However, there is a distinct lack of critical interrogation of claims the field makes (Bayne, Gallagher, Lamb 2014; Bayne, Knox, \& Ross, 2015). While the promises of inclusion and equity in open education may seem relatively attainable, advancement of open education must draw from rigorous investigation of these assumptions rather than swift acceptance (Bayne, Knox, \& Ross 2015). The dearth of critical scholarship on open educational practices (OEP) means questions of diversity, equity, and inclusion often go unaddressed or are dismissed outright. In turn, the lack of criticality in open education discourse disproportionately impacts marginalized students in profound ways.

In this conceptual paper, we first explore the ways in which discourse in the field impacts the shape and direction of open education research, practice, and advocacy. We investigate how extant discourse claims to remove barriers to equity, but, simultaneously, how these presumptions may reify these barriers and perpetuate marginalizing practices. Secondly, we identify foundational principles of open educational practices in online higher education that highlight the critical tensions implicit within OEP. Finally, we align these principles to a social justice framework to explore open educational practices for online undergraduate faculty and instructional designers that support efforts toward inclusivity in online higher education.

\section{Mapping the Landscape of Open Educational Practices}

As open education has grown, practitioners and thought leaders have developed a range of terms to describe conceptual developments, information hierarchies, and paradigms to describe movements in the field (Wiley and Hilton, 2018). These terms and their definitions vary across context and are in constant flux (Cronin \& MacLaren, 2018; Koseoglu \& Bozkurt, 2018). Inherent in each term are fundamental assumptions about the role of students and educators in the learning process. Before turning to these assumptions, we offer a summary of definitions related to open education to afford greater clarity. 
This is an author-produced, peer-reviewed version of this article. The final, definitive version of this document can be found online at Distance Education, published by Routledge. Copyright restrictions may apply. doi: 10.1080/01587919.2020.1757410

While this article does not seek to capture the nuance of current terminology within open education as this work has been previously conducted (Cronin \& MacLaren, 2018; Koseoglu \& Bozkurt, 2018), general understandings are provided for the purposes of this paper. The overall movement towards open education includes access to free and revisable educational resources, democratizing the creation of educational resources, and enabling the open sharing of scholarship and data (Cape Town Open Education Declaration, 2007). In approaching the vision offered by open education, open educational practices are the practical methods used to shift educational institutions in a direction towards openness. These institutional practices may include the creation of alternative and community-driven publishing practices, institutional structures supporting the open licensing of faculty, staff, and student-created resources, and the training and funding of faculty and staff to better understand and implement open educational resources and open pedagogy for their classes (Koseoglu \& Bozkurt, 2018). OEP seek to reconfigure traditional learning topologies from top-down knowledge transfers to a collaborative praxis which positions students as central participants in the knowledge sharing process.

Online, these practices hinge on technology-mediated learning in which participants connect to one another via technical infrastructures. Thus, online OEP understands learning to be relational, contextual, unpredictable, and constantly negotiated rather than linear, hierarchical, or standardized. This framing emphasizes technological infrastructure as a conduit for student participation as well as knowledge creation and transfer, rejecting notions of knowledge as fixed or complete but rather as an ephemeral, emergent phenomenon.

In support of the larger goals of open education, open pedagogy is an instructional approach that seeks to address the underlying inequity of knowledge creation in academic culture by democratizing educational resources. This is achieved through both instructor and student-led creation of renewable assignments, collaborative learning experiences, and instruction in copyright and intellectual property. In doing so, it seeks to create more pertinent, iterative, and transferable learning in a digital world (DeRosa \& Jhangiani, 2017).

While still contested, open pedagogy and its practices are, broadly, individual instructional methods that may manifest in courses that leverage the use of open licenses. Hegarty (2015) conceptualizes open pedagogy as having eight key attributes including participatory technology; people, openness, and trust; innovation and creativity; sharing ideas and resources; connected community; learner generated; reflective practice; and peer review. In doing so, Hegarty's work acknowledges that open pedagogy involves the open critique of others' scholarship. At its core, open pedagogy postures students as contributors to a shared corpus of knowledge. This co-construction of knowledge embraces plurality and trusts students as experts of their lived experiences. In doing so, it may serve to dismantle rigid expectations of what knowledge is, whose knowledges are being shared and learned, and what knowledges could be. Moreover, it may loosen absolute frames of reference, engaging participants to reflect on their own understandings and expertise. As such, open pedagogy has profound implications for epistemology and the production of knowledge.

In a similar vein, OER-enabled pedagogy is the pedagogical application of renewable course assignments that leverage the use of open licenses to revise, remix, reuse, retain, and redistribute educational resources (Wiley \& Hilton, 2018). This definition prioritizes the uniquely disruptive nature of open licenses in the educational space. That being said, it does not fully encompass the dynamic range of pedagogical practices that openness can entail.

In the context of distance education and for the scope of this paper, we opt to primarily focus on the term OEP. OEP encompasses many of the educational practices (both institutional and pedagogical) that are vital for pursuing equitable open education. It centers the pedagogical and systemic impacts of open education rhetoric on the ongoing work of inclusion and equity in higher education, recognizing that institutional infrastructure and pedagogical practice are often deeply interwoven.

\section{Impacts of Open Education Discourse on Inclusion and Equity}

In its nascency, open education has become a "highly charged and politicised term" (Bayne, Knox, \& Ross, 2015, p. 247) where the promise of open education catalyzes action in higher education administration, institutional infrastructure, and academic systems. However, open education often leaves critical conversations about its efficacy and limitations on the periphery. Rises in the cost of education, tensions surrounding learning objectives and public education policy, additional budget constraints, and demands for increasing retention and graduation present a seemingly clear case for the free or low-cost course materials and solutions (Ehlers, 2011; Knox, 2013a; Lambert, 
This is an author-produced, peer-reviewed version of this article. The final, definitive version of this document can be found online at Distance Education, published by Routledge. Copyright restrictions may apply. doi: 10.1080/01587919.2020.1757410

2018). Not only does open education provide an administrative and instructional answer to these challenges, but the nature of open education promises a new way to achieving the notion of a global, democratic, and boundless education commons.

Yet at the same time, the implied virtue of open education provides a discursive shield from critical interrogation of its assumptions. These assumptions, particularly those that claim open education will necessarily catalyze progress (or that open inherently means inclusive) have been embedded into the core of the movement such that critique is often considered passé, unfairly cynical, or completely ignored (Watters, 2014; Watters, 2017). Critical voices are often dismissed as naysayers to open education as its perceived virtue leaves little room for challenge and interrogation (Bayne, Knox, \& Ross, 2015). Often viewed as detractors, critical conversations are frequently shut down (Gourlay, 2014).

Situating considerations of social justice within a larger context of fieldwide discourse is imperative as the language of education technology and education research have material consequences on the lived experiences of students and faculty. In academic conversations, language is not apolitical but "infused with issues of power, privilege, ideology and politics," and "what is said about digital technology also acts to shape the ongoing educational conditions in terms of the knowledge, social relations, and social identities that surround them" (Selwyn, 2015). The generative property of discourse allows it to shape and transform the field. What open education sets out to accomplish is directly informed by these issues; language of education research and praxis shape educational applications, which in turn help shape institutional objectives, priorities, and allocation of resources at the university. The emergent discourse of the open education movement is, therefore, a critical component in creating the anatomy of the open education movement and the realities and direction of online learning (Selwyn, 2015).

Noting the transformative power of open education discourse, interrogations of its emancipatory language can reveal a circular, self-fulfilling narrative that might reify the very structures open education seeks to dismantle. The emergent discourse of the open education zeitgeist is often reminiscent of ideological advocacy and often founded on emotive bases rather than theoretical, empirical, and/or ethnographic groundings (Gourlay, 2014). These bases are similar to discourse surrounding distance education and online learning at large (Bayne, Gallagher, Lamb, 2014). Substantive research on the pedagogical implications of open education, openly accessible information, and learning environments is in short supply (Banzato, 2012; Hood \& Littlejohn, 2018; Knox 2013b; Rolfe 2017). Whereas discourse plays a role in enculturation and discipline-wide socialization (Hope, 2015), it incentivizes researchers and practitioners to adopt a set of values within open education. As such, examining the field's discourse and its impact on the values and priorities of open education is imperative to identifying ways in which OEP can negatively affect marginalized populations.

Through totalizing discourse that touts the benefits of open education without critically assessing its assumptions, academics and leaders have the potential to normalize and propagate problematic practices. The absence of justiceoriented considerations may amplify the potential for socially constructed norms, values, and priorities to do harm, particularly when minimizing or dismissing diversity, equity, and inclusion. Dominant narratives and unchecked assumptions may tacitly reify entrenched institutional and social hierarchies by overlooking, invalidating, or ignoring the lived experiences of students and faculty (Gourlay, 2014). As a result, the particular lack of critical engagement with issues of diversity, inclusion, and equity can have a profound effect on marginalized students which may be amplified in the online learning environment. As the field advances, expanding a comprehensive and critical framework to explore these questions allows the movement to address the underpinning structures of power and control, resisting hegemonic narratives that may unintentionally marginalize or harm.

This is not to say proponents of open education have neglected inclusion and equity; rather it demonstrates the imperative to reinforce those conversations through intentional and coordinated efforts. The need for engaged critique goes beyond superficial acknowledgments of social justice but requires involved and rigorous investigations into how open education achieves or problematizes notions of inclusion. Thus, as the field progresses, the imperative is not to reject the groundswell of open education, but to engage with overlooked or under-acknowledged inequities which these practices may perpetuate. This is especially imperative when current discourse surrounding open education is aligned with the marketization and commodification of the field (Knox, 2013b). By exploring open education at its root assumptions, practitioners can transform the field into additional pathways toward education justice. 
This is an author-produced, peer-reviewed version of this article. The final, definitive version of this document can be found online at Distance Education, published by Routledge. Copyright restrictions may apply. doi: 10.1080/01587919.2020.1757410

\section{$\underline{\text { A Social Justice Framework for Open Educational Practices }}$}

By aligning OEP to a social justice framework that centers marginalized communities, researchers can shift the discursive paradigm of framing justice topics in the negative and instead foster productive change. In addition, the reframing allows researchers and practitioners to shift the analysis from individuals and idiosyncratic experiences to an analysis of systems (Strunk \& Betties, 2019).

Lambert's framework for social justice (2018) builds on previous models of social justice, particularly the work of Keddie (2012), Fraser (2008) and Crenshaw (1989). Lambert proposes a model for understanding open educational resources (OER) through social justice and can be expanded to support OEP at large. She aims to bring to the surface the ways in which the potential of open licenses to allow for transformation often falls short of the reality. Lambert defines open education as "the development of free digitally enabled learning materials and experiences primarily by and for the benefit and empowerment of non-privileged learners who may be under-represented in education systems or marginalised in their global context" (p. 239). As such, this paradigm measures the success of open education by its enactment of social justice (Lambert, 2018). If OEP is approached similarly to this paradigm of OER, opportunities to make explicit and actionable commitments to equity become available. Rather than assuming that socially just educational outcomes "flow from the affordances of our technologies" Lambert's definition asks practitioners to "design explicitly for it" (p. 227).

Lambert identifies three types of social justice - all of which can be enacted through the decisions faculty make about their course materials. Redistributive, recognitive, and representational justice can be defined as:

- Redistributive - "allocation of material or human resources towards those who by circumstance have less"

- Recognitive - "recognition and respect for cultural and gender differences"

- Representational - "equitable representation and political voice" (p. 227).

Redistributive, representational, and recognitive justice form the foundation of a more intentional approach to leveraging open licenses for systemic curriculum change. While redistributive justice is quite closely connected to the goals of OER, recognitive and representational justice are also essential for equity in educational outcomes. This paper seeks to synthesize principles of inclusive open education with this tripartite model of justice to recommend practices that may advance efforts towards inclusion and equity.

\section{Presumptions and Critical Tensions within Open Educational Practices}

Understanding the implicit values, priorities, and power structures embedded in open education advocacy and research is imperative to exposing critical tensions OEP may present. While early proponents of open education laud the ways in which it can embrace social difference to achieve greater educational equity in higher education (DeRosa \& Robison, 2017) these aims cannot be achieved without critical reflexivity about oneself and facility in navigating social difference. Despite framing learning as relational and collaborative, OEP may also heighten concerns regarding power and privilege in the online classroom.

By underscoring social relations and shared contributions to a common space, proponents of OEP must grapple with the tensions associated with mitigating harm while appreciating difference. These tensions are often multifaceted, overlapping, and entangled. Moreover, these tensions are pronounced in the online learning environment where traditional methods of inclusion and equity manifest in different ways. The following themes may help conceptualize potential harms of uncritical OEP, though they cannot and do not explain all considerations of inclusive design. Further rigorous examination of each of these phenomena is necessary as the field advances.

\section{Presumptions of the Self-Directed, Autonomous Student}

A central component of OEP is the relationship between student activity, autonomy, and self-regulation (Paskevicius \& Irvine, 2019). OEP often frames the autonomous student as a source of knowledge generation, where the student develops OER materials to share with peers, the instructor, and often, the world. This approach has far-reaching implications on the reconfiguration of the roles of student and instructor. 
This is an author-produced, peer-reviewed version of this article. The final, definitive version of this document can be found online at Distance Education, published by Routledge. Copyright restrictions may apply. doi: 10.1080/01587919.2020.1757410

The presumption that students will self-direct towards predefined institutional goals have gone largely unchallenged (Knox, 2013a), and a utopia where students can equally self-direct without the guidance, expertise, or scaffolding is contradictory to critical educational theory (Gourlay, 2014). Moreover, the assumption that each student ought to be autonomous, independent, and self-directed privileges some students above others. When these assumptions propagate, disparities in the online classroom are often overlooked, impacting a student's learning, sense of community, and participation.

\section{Placelessness and Proximity in Online Learning}

To understand the situated nature of learning, it is necessary to explore how social identities and environments impact the negotiation of knowledge (Kitchens, 2009). All knowledge is influenced by the social conditions of its creation (Mann \& Kelley, 1997). This is particularly complex and may appear as relationships among students, relationships between students and the instructor, or relationships to course material. In the online setting, this complexity grows as learning and knowledge construction are mediated differently in face-to-face and distance learning environments. Online, each of these relationships is mediated by technology, and this sociomaterial entanglement is part of the generative learning and knowledge building process. However, being mediated by technology creates potential for social identities to be highlighted or masked in harmful ways. This may include student stratification and social exclusion, privileging and centering dominant voices and identities, and calcifying the margins historically underrepresented students may be forced to occupy.

In theory, distance education enables learning to be physically placeless. As such, it is often praised for being a method of education that overcomes the barriers of distance (Luo, Robinson, \& Detwiler, 2014). However, in reality, learning is not a placeless endeavor (Patel, 2015). When practitioners operate on perceived placelessness, they risk the erasure of identities that deeply inform students' lives. Placelessness might position faculty to presume that a student's learning context is much like their own. In essence, the underlying assumption of placelessness removes context as a deeply informative part of understanding educational outcomes. Educators not equipped to interrogate the placelessness of online learning may erase or minimize diversity.

Furthermore, without a commitment to understanding placelessness, faculty, designers, and researchers are, particularly in online learning, left to imagine the students they are working with. In that process of imagining, implicit bias operates freely. With a lack of diversity across higher education and implicit bias, assumptions about one's students rely on one's experiences and perceptions. This may yield an assumption of an average student who tends to hold multiple privileges, as these reflect the identities and beliefs of the educators and designers themselves.

\section{The Labor of Knowledge Creation}

OEP pose critical challenges with inequity particularly by shifting the labor of knowledge production to students. This is particularly troubling in light of the current dearth of resources that support zero-cost textbook programs. While the amount of available OER increases rapidly each year, interest in the field has often outpaced the number of willing faculty who could serve as authors of these resources. In many ways, OEP is a response to this lack of resources by creating the conditions for OER labor to be produced within (and not simply for) courses. As a result, there are ethical implications for off-loading educational resource development onto the students who should, in theory, be benefiting from free and open access to those materials. Concerns around labor inequity, particularly the extraction of student labor, have far-reaching implications for marginalized students. OEP creates potential for individual students to be implicated, targeted, and expected to perform social identities in course assignments for the benefit of their peers. Potential also exists for marginalized student contributions to be extracted and appropriated not only by other students but the institution itself.

In addition to extracting free labor from students, identity-based tokenism and appropriation of ideas are major tensions that could have a harmful impact on marginalized student populations. Without critical reflection, OEP can structure assignments that prioritize the creation and sharing of content over respect for students and their communities. 
This is an author-produced, peer-reviewed version of this article. The final, definitive version of this document can be found online at Distance Education, published by Routledge. Copyright restrictions may apply. doi: 10.1080/01587919.2020.1757410

\section{$\underline{\text { Inclusive Learning Space }}$}

OEP seeks to build relationships of trust between and among instructors and students in order to generate participation in the learning space. However, in the process of doing so, students may experience pressure to create work that could be shared publicly not only with future student cohorts but also freely on the web. While the contribution to the commons might be heralded as a central benefit of OEP, serious concerns of data de-identification, surveillance, public performativity, safety, and privacy have not been key focuses of the discourse.

In the learning space of an online course utilizing OEP, assignments may be built on the tacit assumption that students will feel empowered to share their work under open licenses, particularly to develop a repository of online resources. Without critical reflection, OEP may assume students will be driven by the same moral reasoning as their faculty: that sharing one's work openly and waiving some of one's copyrights is a moral or common-sense thing to do. However, the belief that sharing one's work is an inherent good is a product of cultural values that may not be universally held as concepts of intellectual property are culturally-based and context-specific (Budde-Sang, 2013), and assumptions that students universally share the same motivations or values as dominant discourse must be thoroughly and constantly questioned. The implied assumption of the moral good of open licenses may inherently apply pressure to students to participate when they might otherwise prefer to opt-out. For this reason, it is vital to ensure academic protections for populations historically disbarred from contributing to academic discourse (or who have had their contributions to knowledge erased, minimized, or appropriated).

In addition, the assumption that open learning spaces are accessible might not always be the case, particularly in the context of the hidden curriculum (Anderson, 2001), a concept that illuminates the disguised, implicit social norms of higher education that are not explicitly taught to students. These hidden knowledges can drastically affect the experience of learning and navigating an academic space, particularly for students not privileged with prior mentorship, access to affordable internet, or intergenerational experience in the university. Given the depth and breadth of the hidden curriculum, OEP may be susceptible to presuming students have these foundational and unnamed knowledges and skills as well as access to fast and reliable technology.

\section{Participant Power, Collaborative, and Identity}

OEP presumes that students have space to collaborate and create new meaning. This perspective assumes that every student's voice and contributions will be equally acknowledged and validated and that systems of power and privilege related to race, gender, class, ability, and sexuality can be suspended (Gourlay, 2014). However, the experiences of minoritized identities online often do not reflect this assumption. Instead, power, positionality, and identity play significant roles in negotiating participation online.

In reality, students with marginalized identities may face challenges related to stereotype threat, implicit bias, and imposter syndrome. They may also struggle to navigate issues of assimilation, appropriation, and erasure with their peers. Significantly, emphasis on open collaboration and contribution may privilege and center students with prior domain-specific knowledge. For example, if a student feels that an instructor is pressuring them to openly-license their materials, they may feel compelled to do so with fear of penalty or exclusion from guided pathways and a positive instructor relationship; this concern may not be shared by students with institutional and social power. The varying power of participants in an online learning environment will inevitably impact opportunities to collaborate equitably. While identity-based social violence, ostracization, and abuse are also frequently experienced in traditional classrooms, OEP online may be especially susceptible to amplifying harm.

\section{Principles of Inclusive Open Educational in Online Learning}

While the affordances of OEP have potential for increasing educational equity, the practice of creating knowledge alongside students is inherently rife with complications, including issues of: safety, appropriation, erasure, assimilation, implicit bias, censorship, power, and labor. Any combination of these complexities may be unintentionally built in to online students' learning experiences based on their and others' identities. In the online environment, these tensions are mediated by and through technology, often without campus-based support easily accessible or available for students at a distance. As online faculty strive to build relationships with and between students in their online learning community and engage in unconventional, but authentic, assessments, they must also be aware of the ways in which historically underrepresented populations are systematically and socially excluded from full participation. 
This is an author-produced, peer-reviewed version of this article. The final, definitive version of this document can be found online at Distance Education, published by Routledge. Copyright restrictions may apply. doi: 10.1080/01587919.2020.1757410

That is not to say that there are not many possibilities for leveraging the transformative power of OEP to address issues of fundamental inequity. For example, Hood \& Littlejohn (2018) share their exploration through qualitative and quantitative methods of an edit-a-thon as a learning technique to help students recognize and respond to persisting gender biases online. By framing the engagement with public knowledge through critical means, this demonstrates a promising approach to OEP that leverages its strengths for equity both within and beyond the students' learning experiences.

While the tensions previously identified are systemic, it is imperative to generate strategies to ameliorate their impacts on online students. The following principles offer an exploratory direction for mitigating the impact of oppression in postsecondary education when designing OEP for online students. These strategies are neither complete nor exhaustive, and it is the hope of the authors that the field will advance the spirit of these strategies.

\section{Cultivating an Appreciation for Lines of Social Difference}

Hughes (2007) proposes the concept of identity congruence for understanding the ways in which implicit dominance can impact student involvement and engagement in an online learning community. Identity congruence is formed by the alignment (or misalignment) of both explicit or implicit values in an online learning environment. Hughes argues that creating space for both commonalities and differences is key. Acknowledging that identity is always in flux, Hughes proposes the development of online faculty who have skills in "online listening" that allow them to notice discursive issues that may be "between the lines" of discussion boards or assignments so that they can address them quickly and with depth, even as the pose challenges.

The skills explored in Hughes' work regarding "online listening" suggest that online faculty must be aware of how a process of Othering may occur, further impacting identity congruence. Othering offers an opportunity to enforce power structures and ensure that knowledge construction remains a tool for social control (Phirangee \& Malec, 2017). They found predominant themes of Othering in an online learning environment to include professional, academic, and ethnic exclusion. Intentional fostering of social presence by the faculty, in particular, can help to mitigate the impacts of Othering that may arise from peer-to-peer interactions. Faculty must be not just cognizant of difference but also support students to cultivate an appreciation for the value the difference brings.

\section{Creating Inclusive Spaces for Contribution and Collaboration}

A main feature of OEP is its involvement of the learner in the formulation of their own learning design. As such, it is imperative to create safe, welcoming spaces for students to offer contributions. With awareness of issues of stereotype threat and imposter syndrome, faculty can facilitate a community that values the knowledge of people from a wide variety of backgrounds. Faculty who use their instructor presence to bring to light historical patterns of exclusion can help students from historically underrepresented populations advance in the discipline.

In practice, this may include helping students to identify gaps in the curriculum, particularly those that may pertain to the inequitable or oppressive conditions that shaped the field of study. It may also appear as creating space for authentic collaboration that takes into account the power dynamics and differentials between students of different identities and backgrounds. Methods of doing so include creating community ground rules that help students navigate points of disagreement while working collaboratively (which should be provided alongside a clear and encouraging process for escalating issues for instructor mitigation and support) as well as scaffolding authentic assessment in a manner that provides students with opportunities to iterate based on constructive feedback.

\section{Fostering an Environment that Respects Student Privacy and Autonomy}

Student authorship inherently includes issues of student data, privacy, and autonomy. Instructors must be mindful of ways in which OEP assumes that students will openly license their work. To navigate these issues, instructors may consider fostering an environment that relies on a student's rights to learn without sharing their processes or products publicly. By offering OEP as an opt-in option, instructors can shift the dynamic from one of required public performances to one of autonomy and self-efficacy. Students who opt-in to share their work might do so as an extension of their pride in their ideas and could be a positive contributor to building their self-efficacy as learners. 
This is an author-produced, peer-reviewed version of this article. The final, definitive version of this document can be found online at Distance Education, published by Routledge. Copyright restrictions may apply. doi: 10.1080/01587919.2020.1757410

In practice, this looks like (i) avoiding designing assignments that rest on the assumption that students will waive some of their copyrights and chose an open license, (ii) offering clear alternatives to openly sharing their work so students are aware of all their choices throughout the assessment, and (iii) allowing the use of pen names or for students to be anonymous if preferred.

\section{Facilitating Conversations around Academic Integrity and Open Education}

An often overlooked aspect of OEP is the way in which attribution and citation practices have unresolved tensions. These tensions that inform the way students and faculty write and cite their work in the creation of OER undoubtedly has an impact on OEP. Yet, little work has been done on how to address these tensions and the implications they may carry particularly difficult consequences for marginalized student populations.

Transparent conversations about how citation and attribution differ as academic practices are vital. For many students who are learning disciplinary citation styles, open licenses may obfuscate the clarity of when citation should occur, particularly when it comes to the differences between paraphrasing, remixing, and quoting of others' materials in their own work. As such, careful conversations about open licenses' remix component can help frame the nuances of plagiarism and attribution.

\section{Principles of Inclusive Open Educational in Online Learning}

As the principles outlined above may form a foundation for an equitable approach to OEP in the online classroom, their efficacy is contingent upon continual reflective work aligned to principles of social justice. By drawing on Lambert's model of social justice for OER and mapping the principles of inclusive open education, specific practices that afford greater inclusivity and equity in the online classroom can be explored. These recommended practices are included below.

\section{[See Table 1]}

Of key importance are the ways in which each pedagogical strategy can be implicated in representational, recognitive, and redistributive methods of achieving justice. Each practice offers an opportunity for not just better representation, but also to transform knowledge and bring healing to harmful ideologies embedded throughout higher education. By framing the thoughtful design of OEP onto Lambert's model for just open education, instructional designers and faculty may be better able to ascertain productive strategies for inclusive design.

\section{Conclusion}

As attention towards open education grows, discourse surrounding the use of OEP is often rooted in language of promise and progress. While the potential for OEP to increase access to course materials and participation in learning environments is encouraging, access does not inherently mean inclusion (Watters, 2014). Moreover, discursive analysis of the field illustrates the tendency toward emotive rhetoric and ideological zeal (Gourlay, 2014). This is particularly problematic as open education, in spirit, attempts to radically alter and remove barriers to education, and remains relatively inscrutable to critical engagement (Bayne, Knox, \& Ross 2015). As Freire (2005, p. 54-55) writes, "Pedagogy which begins with the egoistic interests of the oppressors (an egoism cloaked in the false generosity of paternalism) and makes of the oppressed the objects of its humanitarianism, itself maintains and embodies oppression."

OEP have complexities specific to diversity, equity and inclusion. In particular, these complexities highlight social identities such as race, class, gender, sexuality, ability, nationality, and other identities. In order to shape OEP to be inclusive, respectful of differences, and equitable, they must be critically examined under a lens of social justice. Further, to investigate the ways in which OEP might reify marginalization and exclusion, it is necessary to explore the sociopolitical substrate of the learning environment, question uncritical rhetoric of open education, and challenge assumptions it makes about students. This article presents a reflection on the field's discourse and offers a foray into addressing critical tensions, the authors invite open education researchers and practitioners to center conversation on principles of social justice, diversity, equity, and inclusion and advance a critical reframing of OEP. 
This is an author-produced, peer-reviewed version of this article. The final, definitive version of this document can be found online at Distance Education, published by Routledge. Copyright restrictions may apply. doi: 10.1080/01587919.2020.1757410

\section{References}

Banzato, M. (2012.) A case study of teachers' open educational practices. Journal of E-learning and Knowledge Society, 8(3). DOI: https://doi.org/10.20368/1971-8829/650

Bayne, S., Gallagher, M.S. \& Lamb, J. (2014). Being 'at' university: the social topologies of distance students. Higher Education, 67, 569-583 doi:10.1007/s10734-013-9662-4

Bayne, S., Knox, J., \& Ross, J. (2015) Open education: the need for a critical approach. Learning, Media and Technology, (40)3, 247-250, DOI: 10.1080/17439884.2015.1065272

Bonica, M., Judge, R., Bernard, C. \& Murphy, S. (2018). Open pedagogy benefits to competency development: From sage on the stage to guy in the audience. Journal of Health Administration Education, 35(1), 9-27.

Budde-Sung, A. (2013). The invisible meets the intangible: Culture's impact on intellectual property protection. Journal of Business Ethics, (117)2, 345-359. from www.jstor.org/stable/42001853

Cronin, C. (2017). Opening up open pedagogy. Retrieved from http://catherinecronin.net/research/opening-up-openpedagogy/.

Cape Town Open Education Declaration. (2007). Cape Town open education declaration: Unlocking the promise of open educational resources. Retrieved from http://www.capetowndeclaration.org/read-the-declaration

Colvard, N.B., Watson, C.E., \& Park, H. (2018). The impact of open educational resources on various student success metrics. International Journal of Teaching and Learning in Higher Education, (30)2, 262-276.

Crenshaw, K. (1989). Demarginalizing the intersection of race and sex: A black feminist critique of antidiscrimination doctrine, feminist theory, and antiracist politics. University of Chicago Legal Forum, 1989(1), 139-167.

Cronin, C., \& MacLaren, I. (2018). Conceptualising OEP: A review of theoretical and empirical literature in open educational practices. Open Praxis, 10(2), 127-143. Retrieved from http://dx.doi.org/10.5944/openpraxis.10.2.825

DeRosa, R., \& Jhangiani, R. (2017). Open Pedagogy. In E. Mays (Ed.), A Guide to Making Open Textbooks with Students. Montreal, Quebec: Rebus Community.

DeRosa, R., \& Robison, S. (2017). From OER to open pedagogy: Harnessing the power of open. In: Jhangiani, R S and Biswas-Diener, R. (eds.) Open: The Philosophy and Practices that are Revolutionizing Education and Science. (115-124). London: Ubiquity Press. DOI: https://doi.org/10.5334/bbc.i.

Ehlers, U. (2011). Extending the territory: From open educational resources to open educational practices. Journal of Open, Flexible and Distance Learning, 15(2), [1-10].

Fraser, N., \& Olson, K. (2008). Adding insult to injury: Nancy Fraser debates her critics. London: Verso.

Freire, P. (2005). Pedagogy of the oppressed (M. Bergman Ramos, Trans.). New York, NY: Continuum. (Original work published 1970).

Gourlay, L. (2015). Open education as a 'heterotopia of desire.' Learning, Media and Technology, 40(3), 310-327, DOI: 10.1080/17439884.2015.1029941

Hegarty, B. (2015). Attributes of open pedagogy: A model for using open educational resources. Educational Technology, 55(4), 3-13.

Hood, N., \& Littlejohn, A. (2018). Hacking history: Redressing gender inequities on Wikipedia through an editathon. International Review of Research in Open and Distributed Learning, 19(5). https://doi.org/10.19173/irrodl.v19i5.3549

Hope, A. (2015.) Foucault's toolbox: Critical insights for education and technology researchers. Learning, Media, and Technology, 38(2), 160-172. https://doi.org/10.1080/17439884.2014.953546.

Hughes, G. (2007). Diversity, identity, and belonging in e-learning communities. Teaching in Higher Education: Critical Perspectives, 12(5-6), 709-720. https://doiorg.libproxy.boisestate.edu/10.1080/13562510701596315

Keddie, A. (2012). Schooling and Social Justice Through the Lenses of Nancy Fraser. Critical Studies in Education, $53(3), 263-279$.

Kitchens, J. (2009). Situated pedagogy and the situationist international: Countering a pedagogy of placelessness, Educational Studies, 45(3), 240-261, DOI: 10.1080/00131940902910958

Knox, J. (2013a). The limitations of access alone: Moving towards open processes in education technology. Open Praxis, 5(1): 21-29. DOI: https://doi.org/10.5944/openpraxis.5.1.36

Knox, J. (2013b). Five critiques of the open educational resources movement. Teaching in Higher Education, 18(8), 821-832. DOI: $10.1080 / 13562517.2013 .774354$

Koseoglu, S., \& Bozkurt, A. (2018). An exploratory literature review on open educational practices. Distance Education, 39(4), 441-461. https://doi.org/10.1080/01587919.2018.1520042 
This is an author-produced, peer-reviewed version of this article. The final, definitive version of this document can be found online at Distance Education, published by Routledge. Copyright restrictions may apply. doi: 10.1080/01587919.2020.1757410

Lambert, S. (2018). Changing our (dis)course: A distinctive social justice aligned definition of open education. Journal of Learning for Development, 5(3), 225-244.

Lerman, S. R., Miyagawa, S. \& Margulies, A. H. (2008). OpenCourseWare: Building a culture of sharing, in T. Iiyoshi and M. S. V. Kumar (eds), Opening Up Education: The Collective Advancement of Education through Open Technology, Open Content, and Open Knowledge (pp. 213-227), MIT Press, Cambridge, MA

Luo, H., Robinson, A., \& Detwiler, J. (2014). Effect of geographic distance on distance education: An empirical study. Journal of Educators Online, 11(3), 4-17.

Mann, S. A., \& Kelley, L. R. (1997). Standing at the crossroads of modernist thought. Gender \& Society, 11(4), 391-408. DOI: $10.1177 / 089124397011004002$

Paskevicius, M. \& Irvine, V. (2019). Practicalities of implementing open pedagogy in higher education. Smart Learning Environments, 6(23). https://doi.org/10.1186/s40561-019-0110-5

Patel, L. (2016). Decolonizing educational research: From ownership to answerability.

Phirangee, K. \& Malec, A. (2017). Othering in online learning: an examination of social presence, identity, and sense of community. Distance Education, 38(2), 160-172, DOI: 10.1080/01587919.2017.1322457

Pierce, M. (2016). Looking at OER with a critical eye: Strengthening OER initiatives by focusing on student learning. Community and Junior College Libraries (22), 11-17.

Rolfe, V. (2017). Striving toward openness: But what do we really mean? The International Review of Research in Open and Distributed Learning, 18(7). DOI: https://doi.org/10.19173/irrodl.v18i7.3207

Selwyn, N. (2015). The discursive construction of education in the digital age. In R. H. Jones, A. Chik, \& C. A. Hafner (Eds.), Discourse and Digital Practices: Doing Discourse Analysis in the Digital Age (pp. 226 240). Abingdon Oxon UK: Routledge.

Strunk, K. K., \& Betties, J. S. (2019). Using Critical Theory in Educational Research. Research Methods for Social Justice and Equity in Education, 71-79. doi: 10.1007/978-3-030-05900-2 6

Watters, A. (2014). From "open" to justice \#opencon2014.

Watters, A. (2017). http://audreywatters.com/2017/07/29/open-pedagogy

Wiley, D., \& Hilton III, J. L. (2018). Defining OER-enabled pedagogy. The International Review of Research in Open and Distributed Learning, 19(4). https://doi.org/10.19173/irrodl.v19i4.3601

Winitzky-Stephens, J. R., \& Pickavance, J. (2017). Open educational resources and student course outcomes: A multilevel analysis. The International Review of Research in Open and Distributed Learning, 18(4). https://doi.org/10.19173/irrodl.v18i4.3118 
Table 1: Mapping OEP to Lambert's Representation of Open Educational Justice

\begin{tabular}{|c|c|c|c|}
\hline $\begin{array}{l}\text { Pedagogical } \\
\text { Practice }\end{array}$ & Representational Justice & Recognitive Justice & Redistributive Justice \\
\hline $\begin{array}{l}\text { Cultivate an } \\
\text { Appreciation for } \\
\text { Lines of } \\
\text { Difference }\end{array}$ & $\begin{array}{l}\text { Model safe disclosure of identity } \\
\text { (i.e., ask for and use gender } \\
\text { pronouns) and allow students to } \\
\text { disclose differently in different } \\
\text { venues. } \\
\text { Avoid highly idiomatic language in } \\
\text { open educational assignments, } \\
\text { explanations, and materials. }\end{array}$ & $\begin{array}{l}\text { Affirm diverse ways of knowing in } \\
\text { both written material and other } \\
\text { communication with students. } \\
\text { Encourage students to explore gaps } \\
\text { in the curriculum particularly when } \\
\text { they involve historically } \\
\text { underrepresented populations. }\end{array}$ & $\begin{array}{l}\text { Model reflection on one's } \\
\text { implicit biases. } \\
\text { Follow an inclusive design } \\
\text { guide when developing an } \\
\text { online course, particularly in } \\
\text { light of co-creating } \\
\text { knowledge and educational } \\
\text { materials. Use visuals that do } \\
\text { not reinforce stereotypes. }\end{array}$ \\
\hline $\begin{array}{l}\text { Create Space for } \\
\text { Contribution and } \\
\text { Collaboration }\end{array}$ & $\begin{array}{l}\text { Co-create communication and } \\
\text { language guides. } \\
\text { Create smaller assignments that help } \\
\text { students acquire the skills needed to } \\
\text { complete a larger, more } \\
\text { comprehensive assignment. }\end{array}$ & $\begin{array}{l}\text { Affirm student contributions to } \\
\text { mitigate erasure. } \\
\text { Recognize potential for student- } \\
\text { generated content to be exploited, } \\
\text { appropriated, or misused. }\end{array}$ & $\begin{array}{l}\text { Develop a plan for } \\
\text { addressing identity-based } \\
\text { conflict in online discussion } \\
\text { boards. } \\
\text { Embrace emergent and } \\
\text { generative participant } \\
\text { contributions that may take } \\
\text { plans off track. }\end{array}$ \\
\hline
\end{tabular}




\begin{tabular}{|c|c|c|c|}
\hline $\begin{array}{l}\text { Foster an } \\
\text { Environment that } \\
\text { Respects Student } \\
\text { Privacy \& } \\
\text { Autonomy }\end{array}$ & $\begin{array}{l}\text { Establish safety through shared } \\
\text { agreements and co-created } \\
\text { participant boundaries. } \\
\text { Have students decide how to license } \\
\text { their contributions. Provide adequate } \\
\text { and detailed information for } \\
\text { informed decision-making. }\end{array}$ & $\begin{array}{l}\text { Create a plan for gathering } \\
\text { informed consent to use student } \\
\text { data, acknowledging ways in which } \\
\text { data has been historically } \\
\text { weaponized against marginalized } \\
\text { communities. } \\
\text { Ensuring that any course outputs } \\
\text { are not tied to a particular section or } \\
\text { year to protect students educational } \\
\text { enrollment privacy. }\end{array}$ & $\begin{array}{l}\text { Create opt-in opportunities } \\
\text { for sharing contributions } \\
\text { beyond the classroom } \\
\text { environment. } \\
\text { Allow students to make use } \\
\text { of a pen names or to remain } \\
\text { anonymous when openly } \\
\text { sharing their work. }\end{array}$ \\
\hline $\begin{array}{l}\text { Facilitate } \\
\text { Conversations } \\
\text { around Academic } \\
\text { Integrity and } \\
\text { Open Education }\end{array}$ & $\begin{array}{l}\text { Ensure diverse representation on } \\
\text { student conduct boards for academic } \\
\text { dishonesty cases. } \\
\text { Discuss how issues of idea } \\
\text { ownership vary culturally and } \\
\text { temporally. }\end{array}$ & $\begin{array}{l}\text { Create plans to build a common } \\
\text { understanding of academic } \\
\text { integrity principles. Understand } \\
\text { and explore cross-cultural notions } \\
\text { of ownership. } \\
\text { Explicitly discuss negligent } \\
\text { academic dishonesty in student- } \\
\text { friendly language. }\end{array}$ & $\begin{array}{l}\text { Adopt an education-oriented } \\
\text { model for academic } \\
\text { dishonesty or student } \\
\text { misconduct. } \\
\text { Allocate time and resources } \\
\text { to meeting with students } \\
\text { individually to explore } \\
\text { academic integrity with } \\
\text { positive support. }\end{array}$ \\
\hline
\end{tabular}

